\title{
Partial Characterization of Chitosanase from Bacillus cereus Strain BFE5400 Isolated from Snakehead Fish Intestine
}

\section{Karakterisasi Parsial Kitosanase Bacillus cereus Strain BFE5400 yang diisolasi dari Saluran Pencernaan Ikan Gabus}

\author{
Shanti Dwita Lestari*, Ace Baehaki' \& Guttifera Guttifera² \\ Program Studi Teknologi Hasil Perikanan, Fakultas Pertanian, Universitas Sriwijaya, Palembang, Sumatera Selatan, Indonesia \\ 2PDD Akademi Komunitas Negeri Banyuasin, Palembang, Sumatera Selatan, Indonesia \\ *Corresponding author, e-mail: shantidwita_thi@unsri.ac.id
}

Submitted 22 February 2019 Revised 03 April 2019 Accepted 30 June 2020

\begin{abstract}
Abstrak Pola makan ikan gabus (Channa striata) yang memangsa udang dan krustasea kecil menjadikan saluran pencernaannya sumber yang baik untuk mengisolasi enzim maupun mikroba penghasil enzim kitinase dan kitosanase. Tujuan dari penelitian ini adalah untuk mengisolasi bakteri penghasil enzim kitosanase dari saluran pencernaan ikan gabus, memilih isolat dengan indeks kitosanolitik tertinggi dan menggunakannya dalam proses produksi enzim serta melakukan karakterisasi parsial enzim kitosanase ekstrak kasar yang dihasilkan. Hasil penelitian menunjukkan bahwa isolat I2 memiliki indeks kitosanolitik tertinggi dengan nilai 1,5 dengan aktivitas enzim $0,00331 \mathrm{U} / \mathrm{mL}$ setelah 72 jam inkubasi. Densitas bakteri tertinggi berada pada jam ke-24 dengan nilai turbiditas 0,5315. Aktivitas enzim optimal tercapai pada $\mathrm{pH}$ 6, dengan nilai $0,00816 \mathrm{U} / \mathrm{mL}$, sedangkan suhu optimum adalah $70^{\circ} \mathrm{C}$ dengan aktivitas enzim $0,00785 \mathrm{U} / \mathrm{mL}$. Identifikasi genetik isolat $\mathrm{I} 2$ menggunakan $16 \mathrm{~S}$ rRNA menunjukkan bahwa isolat tersebut merupakan Bacillus cereus strain BFE 5400.
\end{abstract}

Kata kunci: Bacillus cereus; kitosanase; ikan gabus; saluran pencernaan

\begin{abstract}
Feeding pattern of wild snakehead fish (Channa striata) which includes shrimp and small crustaceans makes it is intestine a good source of chitinase and chitosanase enzymes. This study aimed to isolate chitosanase producing bacteria from snakehead fish intestine, to select isolate with highest chitosanolytic activity, to produce chitosanase using the selected isolate and partially characterize the resulting enzyme. I2 isolate exhibited the highest chitosanolytic index with the value of 1.5 and produced enzyme with an activity of $0.00331 \mathrm{U} / \mathrm{mL}$ after 72 hours incubation. The ultimate bacterial density was at the $24^{\text {th }}$ hour with a turbidity value of 0.5315 . The enzyme activity was optimum at $\mathrm{pH}$ 6, with a value of $0.00816 \mathrm{U} / \mathrm{mL}$, while the optimum temperature was $70^{\circ} \mathrm{C}$ with the enzyme activity of $0.00785 \mathrm{U} / \mathrm{mL}$. Genetic identification of $\mathrm{I} 2$ isolate using $16 \mathrm{~S}$ rRNA showed that the isolate has a high similarity to Bacillus cereus strain BFE 5400.
\end{abstract}

Key words: Bacillus cereus; chitosanase; snakehead fish; intestine

\section{INTRODUCTION}

The enzyme technology has developed rapidly and occupies an important position in the catalyst industry. The use of enzymes as biocatalyst offers more advantages as they are safer and have high specificity for the substrate compared to traditional chemical catalysts.

Chitosan oligomers or chitosan oligosaccharides are the hydrolysates of chitosan which show a wide range of bioactivity, including antibacterial, antifungal, antioxidant and antimicrobial activity (Ibrahim et al., 2016). Both chemical and physical processes have been used to produce chitosan oligomers by using hydrochloric acid (Kasaai et al., 2013) and ultrasonic irradiation (Kasaai et al., 2008) or combination between degradation method using hydrogen peroxide and microwave radiation (Sun et al., 2007). Employing concentrated hydrochloric acid for chitosan hydrolysis has some drawbacks like harsh conditions, many purification steps to remove the strong acid and low yields of chito-oligomers (Ibrahim et al., 2016). On the other hand, the use of ultrasonic irradiation is only suitable to obtain moderate-size macromolecules due to its partial depolymerization ability. The enzymatic process is known to produce more uniform oligomers with a high degree of polymerization (Shahidi et al., 1999).

Chitosanase is an enzyme that can cleave chitosan polymers. It is generally an endo splitting enzyme and can hydrolyze chitosan to chitosan oligomers and glucosamine as the product of hydrolysis (Chiang et al., 2002). Chitosanase is known to occur widely in various microorganisms such as molds, actinomycetes, and bacteria. The difference between chitosanases from each organism is in their hydrolytic action pattern. This property depends on the degree of acetylation of the substrate. Moreover, the difference in biochemical properties is also observed between chitosanases from various sources (Somashekar \& Joseph, 1996). Therefore, the search for a new source of chitosanase is very important to produce specific-size chitosan oligomers.

The digestive tract of snakehead fish (Channa striata) is a good source of chitinase and chitosanase enzymes. This 
carnivorous fish feeds mainly on live animals such as frogs, small fish, shrimp, and crustaceans. The digestive tract of fish provides a good habitat for bacteria. However, very few reports are available on chitosanase producing bacteria associated with snakehead fish intestine as well as on the characteristics of the enzyme.

\section{MATERIALS AND METHODS}

\section{Materials}

The materials used in this study were physiological salts ( $\mathrm{NaCl} 0.85 \%)$, chitosan from shrimp shell $>75 \%$ deacetylated (Sigma Aldrich), $\mathrm{HCl}, \mathrm{NaOH}, \mathrm{K}_{2} \mathrm{HPO} 4, \mathrm{MgSO} 4.7 \mathrm{H}_{2} \mathrm{O}, \mathrm{NaCl}$, (NH4) ${ }_{2} \mathrm{SO} 4$, phosphate buffer, citrate buffer, citratephosphate buffer, borate buffer, and Schales reagent $\left(\mathrm{K}_{3}\left[\mathrm{Fe}(\mathrm{CN})_{6}\right]\right.$ and $\left.\mathrm{Na}_{2} \mathrm{CO}_{3}\right)$, alcohol, glycerol $85 \%$ emsure (Merck), bacteriological agar and yeast extract (Oxoid), aquadest and sintered glass filter.

Equipment used in the study consisted of vortex, laboratory glassware, autoclave (Hirayama HL36AE, Japan), analytical scales (Ohaus), spectrophotometer (Shimadzu UV1800, Japan), pH meter (Hanna HI98107, USA), incubator shaker, micropipette (Eppendorf), incubator (Memmert IN55, Germany), microtube (Eppendorf), centrifuge (Hettich Universal 320R Benchtop Centrifuge, Germany) and bunsen burner.

\section{Methods}

\section{Media preparation}

Colloidal chitosan was prepared according to Pagnoncelli et al. (2010). Ten grams of chitosan powder was dissolved in 1 $\mathrm{L}$ of $\mathrm{HCl}$ solution $(0.1 \mathrm{M})$ with continuous stirring. Insoluble materials in the suspension were separated by filtration through sintered glass filters. The $\mathrm{pH}$ of the suspension was adjusted to 7.0 by the addition of $10 \mathrm{~N} \mathrm{NaOH}$.

The chitosan broth was prepared by supplementing the Minimal Synthetic Medium which consists of 0,1\% $\mathrm{K}_{2} \mathrm{HPO} 4$, $0,01 \% \mathrm{MgSO} 4.7 \mathrm{H}_{2} \mathrm{O}, 0,1 \% \mathrm{NaCl}, 0,7 \%\left(\mathrm{NH}_{4}\right)_{2} \mathrm{SO} 4$ and 0,05\% yeast extract with $1 \%$ colloidal chitosan (Chasanah et al., 2011). As for chitosan agar, $2 \%$ of bacteriological agar was added to the medium. The media solution was sterilized by autoclaving at $121^{\circ} \mathrm{C}$ for $15 \mathrm{~min}$.

Schales' reagent was prepared by diluting $0.5 \mathrm{~g} \mathrm{~K}_{3}\left[\mathrm{Fe}(\mathrm{CN})_{6}\right]$ in $1 \mathrm{~L} \mathrm{Na}_{2} \mathrm{CO}_{3} 0.5 \mathrm{M}$ to form a $0.5 \mathrm{M}$ sodium carbonate solution containing $0.05 \%$ potassium ferricyanide.

\section{Sample preparation}

Snakehead fish weighing $\pm 1,5 \mathrm{~kg}$ each and a length of \pm 60 $\mathrm{cm}$ were obtained from fish traders at the Indralaya market, Ogan Ilir, South Sumatera. The gut was dissected out from the animal in a-septic condition. The digestive tracts ( $25 \mathrm{~g}$ ) were homogenized in $225 \mathrm{~mL}$ of sterile (pre-autoclaved $\left.121^{\circ} \mathrm{C}, 15 \mathrm{~min}\right)$ physiological saline solution $(0.85 \% \mathrm{NaCl})$ and used as a bacterial stock solution.

Isolation of chitosanase producing bacteria (Setia \& Suharjono, 2015)

Instead of plating directly on chitosan agar, the bacterial stock solution was firstly inoculated into $100 \mathrm{~mL}$ of chitosan broth media in $250 \mathrm{~mL}$ closed laboratory flasks and incubated in incubator shaker $\left(30^{\circ} \mathrm{C}, 150 \mathrm{rpm}\right)$ for
$72 \mathrm{~h}$. This aimed to support the growth of chitosanaseproducing bacteria. After $72 \mathrm{~h}, 0.1 \mathrm{~mL}$ of the sample was transferred into the chitosan agar medium by using the spread plate technique and incubated at $37^{\circ} \mathrm{C}$ for $48 \mathrm{~h}$. Chitosan hydrolysis was indicated by zones of clearing around the colonies. Individual colonies with clear zones were picked from each plate and transferred to subculture. The final quadrant streak was done to obtain pure culture in a single colony.

\section{Chitosanolytic index measurement}

Bacterial isolates with chitosanolytic activity can show clear zones on chitosan agar plates containing colloidal chitosan. The ratio between clear zones diameter and colony diameter is referred to chitosanolytic index. Both clear zones and colony diameter were measured three times by including the longest and the shortest diameter. The average diameter value was used for chitosanolytic index measurement.

\section{Production of crude enzymes}

An isolate giving the highest chitosanolytic index was used in enzyme production. The production of chitosanase enzyme followed the method proposed by Chasanah et al. (2011) with slight modification. One loop of selected isolate colony was grown in a laboratory flask containing $20 \mathrm{~mL}$ of chitosan broth medium. The flask was tightly closed and incubated in an incubator shaker at $37^{\circ} \mathrm{C}, 100 \mathrm{rpm}$ up to $96 \mathrm{~h}$. Culture media was collected and centrifuged for 20 minutes $\left(4^{\circ} \mathrm{C}, 9,000 \mathrm{rpm}\right)$ using Hettich $320 \mathrm{R}$ centrifuge with angle rotor 6 -place. The supernatant produced after centrifugation was considered a crude enzyme solution that will be used in the chitosanase activity test. Duplicate flasks were withdrawn at $24 \mathrm{~h}$ intervals and analyzed for cell growth and enzyme activity. Cell growth was measured by absorbance at $660 \mathrm{~nm}$.

\section{Chitosanase activity (Chasanah et al., 2011)}

Chitosanase activity was assessed by measuring the reducing sugars produced from chitosan hydrolysis. A sample mixture consisting of 150 $\mu \mathrm{L}$ of $1 \%$ colloidal chitosan, $150 \mu \mathrm{L}$ of $0.05 \mathrm{M}$ phosphate buffer $\mathrm{pH} 6.0$ and $150 \mu \mathrm{L}$ of enzyme solution was prepared. Separately, a control mixture was made of $150 \mu \mathrm{L}$ of colloidal chitosan and $150 \mu \mathrm{L}$ of $0.05 \mathrm{M}$ phosphate buffer $\mathrm{pH}$ 6.0. Both samples and controls were then incubated for 30 minutes at $37^{\circ} \mathrm{C}$ followed by enzyme inactivation by boiling for 3 minutes. Subsequently, as much as $200 \mu \mathrm{L}$ of both samples and control were added with $1000 \mu \mathrm{L}$ of Schales' reagent and $800 \mu \mathrm{L}$ of distilled water in $2 \mathrm{~mL}$ microtubes, wrapped in aluminum foil, incubated a water bath (100 ${ }^{\circ} \mathrm{C}, 15 \mathrm{~min}$ ) and cooled. The solution was centrifuged (8000 rpm, $10 \mathrm{~min}$ ) and the reducing sugar formed in the supernatant were estimated spectrophotometrically by measuring absorbance at $420 \mathrm{~nm}$. The value recorded was converted into an amount of glucosamine (GICN) by the standard curve prepared using GlcN.

According to Ferrari et al. (2014), the reaction between reducing sugars obtained from chitinase activity and Schales' reagent will contribute to the fading of yellow color which can be monitored at $420 \mathrm{~nm}$. One unit of chitosanase activity was taken as the amount of enzyme 
that could liberate $1 \mu \mathrm{mol}$ of reducing sugar as glucosamine equivalents per minute under the conditions described above. Glucosamine levels in samples were calculated based on glucosamine standard curves with concentrations of $0,20,40,60,80,100,120,140$, and $160 \mu \mathrm{g} / \mathrm{mL}$.

\section{Determination of optimum $\mathrm{pH}$ and temperature}

Determination of optimum $\mathrm{pH}$ was carried out by reacting enzymes on buffers with a variety of $\mathrm{pH}$ values ranging from 3 to $\mathrm{pH}$ 9. The buffer used in determining the optimum $\mathrm{pH}$ was citrate buffer ( $\mathrm{pH} 3.0-4.0)$, citrate-phosphate buffer $(\mathrm{pH}$ 4.0-6.0), phosphate buffer $(\mathrm{pH} 6.0-8.0)$, boric buffer $(\mathrm{pH}$ 8.0-9.0). The procedure for measuring enzyme activity at each $\mathrm{pH}$ treatment was carried out by the measurement standards described earlier.

The determination of the optimum temperature was done at the enzyme's optimum $\mathrm{pH}$. The temperature variations used in this research were $(30,37,50,60,70$ and $80^{\circ} \mathrm{C}$ ). Initially, the enzyme was mixed with the substrate and phosphate buffer solution in the microtubes. The homogeneous mixture solution was incubated for 30 minutes at the desired temperature. The measurement of enzyme activity at each temperature treatment was carried out similarly to the standard test described earlier.

\section{Identification of isolates}

Two loops of chitosanolytic bacteria were inoculated in nutrient broth (Merck) and incubated overnight at 120 $\mathrm{rpm}, 30^{\circ} \mathrm{C}$. As much as $3 \mathrm{~mL}$ of the culture was centrifuged $(13,000 \mathrm{rpm}, 5 \mathrm{~min})$ and the pellet was used for genome extraction following the method described by Ausubel et al. (1997).

Amplification of 165 ribosomal RNA gene sequence was done using primer pairs of 9F (5'-GAG TTT GAT CCT GGC TCA G-3') and 1541R (5'-AAG GAG GTG ATC CAG CC-3'). The composition of $50 \mu \mathrm{L}$ Kappa ready mix master kit for PCR consisted of $20 \mu \mathrm{L} \mathrm{dH2O}, 25 \mu \mathrm{L}$ PCR master mix, $2 \mu \mathrm{L}$ Primer 9F (20 pmol), $2 \mu \mathrm{L}$ Primer 1541R (20 pmol) and 1 $\mu \mathrm{L}$ template DNA. PCR Thermal Cycler was run with the following programs for 30 cycles: denaturation $\left(96^{\circ} \mathrm{C}\right.$, $30 \mathrm{~s})$, annealing $\left(55^{\circ} \mathrm{C}, 30 \mathrm{~s}\right)$, elongation $\left(72^{\circ} \mathrm{C}, 1 \mathrm{~min}\right)$ and extension $\left(72^{\circ} \mathrm{C}, 7 \mathrm{~min}\right)$.

PCR products were electrophoresed on 1\% agarose gel in TAE $1 \mathrm{x}$ buffer, 100 volts for $30 \mathrm{~min}$ and visualized using gel illuminator. After sequencing, the nucleotide sequences of $16 \mathrm{~S}$ ribosomal RNA was analyzed using NCBI BLAST. The whole identification process was carried out in the Biotechnology Research Center, Indonesian Institute of Science (LIPI).

\section{RESULTS AND DISCUSSION}

Chitosan is a linear nontoxic polycationic polysaccharide consisting of d-glucosamine (GICN) and N-acetyl-dglucosamine (GICNAC) units (Rydz et al., 2018). The chitosanolytic index was calculated by comparing the diameter of the clear zone with the diameter of the colony. The clear zones were varied depending on the ability of bacterial isolates to produce enzyme and hydrolyze colloidal chitosan on agar medium. The magnitude of the clear zone produced depends on the number of monomers
$\mathrm{N}$ - Glucosamine produced from the chitosan hydrolysis process by breaking down the $\beta-1,4$ homopolymer $N$ Glucosamine bond. The greater the number of monomers produced, the greater the clear zones formed around the colonies. Every isolate collected in this research displayed varieties of the chitosanolytic index as presented in Table 1.

Table 1. Chitosanolytic index of isolates.

\begin{tabular}{ll}
\hline Isolates & Chitosanolytic Index \\
\hline 11 & $1.33 \pm 0.11$ \\
12 & $1.5 \pm 0.57$ \\
13 & $1.17 \pm 0.98$ \\
\hline
\end{tabular}

Isolate 12 produced the highest clear zone with the index value of 1.50 and then was used in the production of crude chitosanase. The clear zones around bacterial colonies were started to form after 48 hours of incubation. In another study conducted by Chasanah (2007) in marine bacteria associated with sponges, the incubation time required by the bacteria to obtain chitosanolytic index values was for 5 days ( 120 hours) with cchitosanolytic index values ranging from 1.05-5.40. According to SwiontekBrzezinska et al. (2007), each bacterium has different chitosan degrading speed which depends on several factors such as temperature, substrate concentration, incubation time, and $\mathrm{pH}$.

Chitosanase activity of the culture was determined by the measurement of glucosamine liberated from chitosan by the action of the enzyme under assay condition. The optimum incubation time for enzyme production and highest chitosanase activity was observed in 24, 48, 72, and 96 hours in terms of production of d-glucosamine (GlcN) which was indicative of the degradation of chitosan. The relation between the chitosanase activity of isolate 12 and cell turbidity which was measured as optical density at 660 $\mathrm{nm}$ is presented in Figure 1.

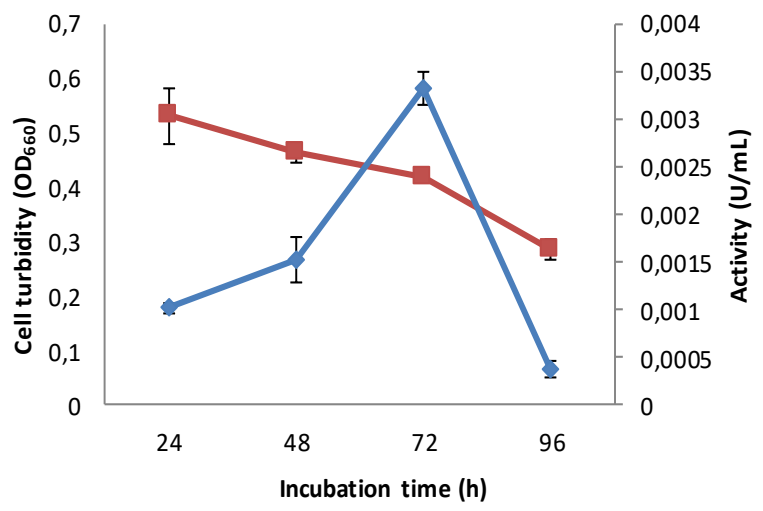

Figure 1. Relation between incubation time, cell turbidity ( ${ }^{-C 1}$ ) and enzyme activity $(\leftarrow \infty)$ of I2 isolate.

The chitosanase activity of 12 isolate showed a slight increase at the first $48 \mathrm{~h}$, but then rocketed and reached the maximum value of $0.00331 \mathrm{U} / \mathrm{mL}$ after $72 \mathrm{~h}$ incubation. However, the activity was then decreased to the lowest activity of $0.00036 \mathrm{U} / \mathrm{mL}$ in the 96th hour. As for the turbidity, cell density decreased steadily from 0.5315 at first $24 \mathrm{~h}$ to 0.2860 at the final observation hour. During their growth, bacteria utilize nutrients such as KDHPO4, 
and MgSO4 which function as enzyme's cofactors and yeast extract as a source of nitrogen. As nutrients depleted, cell growth entered the decline phase. The lag and log growth phases in this research occurred at the time between 0 and $24 \mathrm{~h}$. This result is in line with Chasanah (2007) who found that the log phase of chitosanolytic bacteria started from the 0 to $12 \mathrm{~h}$, stationary phase observed at 16 to 24 $\mathrm{h}$ followed by declining phase at the $48 \mathrm{~h}$. The optimum incubation time of $72 \mathrm{~h}$ with the highest chitosanolytic activity is by the results of Choi et al. (2004) which showed that Bacillus sp. KCTC 0377BP optimally produces enzymes within 72 hours of incubation.

Each enzyme has the optimum $\mathrm{pH}$ and temperature where it displays its maximum activity. The $\mathrm{pH}$ condition of the enzymatic reaction affects the ability of the enzyme to hydrolyze the substrate. The use of correct buffers to maintain the $\mathrm{pH}$ of the reaction is important as an inappropriate buffer and $\mathrm{pH}$ values can lead to disruption of substrates-enzymes interactions. As enzymes are proteins composed of amino acids, the changes in $\mathrm{pH}$ are closely related to the acid-base properties of proteins. Each reaction that is catalyzed by enzymes occurs more quickly at a certain $\mathrm{pH}$. If the medium is very acidic or highly alkaline the enzyme undergoes inactivation. The effects of $\mathrm{pH}$ on isolate 12 chitosanase activity is reported in Figure 2.

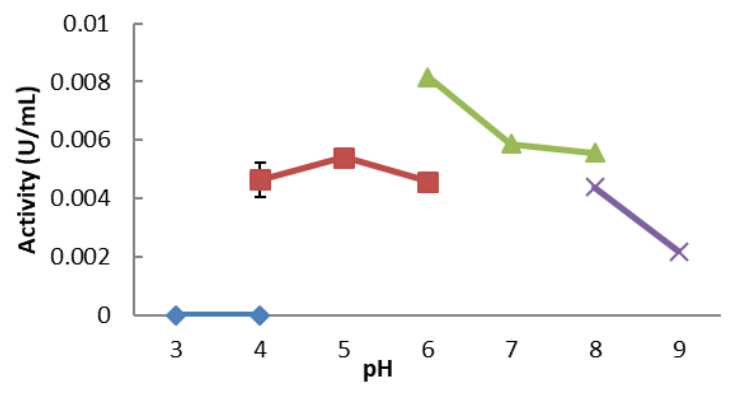

Figure 2. Chitosanase activity of I2 isolate as effected by $\mathrm{pH}$ and buffer types [ citrate $(\rightarrow-\infty)$; citrate-phosphate $(\rightarrow-\mathrm{Cl}$ ); phosphate $(\leftarrow \mathrm{C2})$ and boric $(\leftarrow \mathrm{C})]$.

The crude enzyme activity was tested in various $\mathrm{pH}$ using different buffers to determine the $\mathrm{pH}$ dependence of chitosanase activity. Citrate, citrate-phosphate, phosphate and boric buffers were used to create a range of $\mathrm{pH}$ values in the reaction mixtures. The highest chitosanase activity was obtained at $\mathrm{pH} \mathrm{6,} \mathrm{which} \mathrm{was} \mathrm{equal} \mathrm{to} 0.00816 \mathrm{U} /$ $\mathrm{ml}$. This result is similar to Pagnoncelli et al. (2010) who observed the highest chitosanase activity of Paenibacillus ehimensis at $\mathrm{pH} 6$.

According to Muchtadi et al. (1996), enzymes are ampholytic, which means that they have associative constants in acid groups or their base groups. It is estimated that changes in enzyme activity were due to ionization in the ionic group which plays a role in maintaining the active side conformation in binding the substrate and in converting the substrate into a product. Ionization can also present in substrate or substrate enzyme complex, which also affects enzyme activity. Changing the $\mathrm{pH}$ of the solution changes the number of charged groups on the protein molecules

A rise in temperature to a certain extent in a reaction causes an increase in the speed of the enzyme reaction due to increased kinetic energy which speeds up the vibrational motion, translation and rotation of enzymes and substrates, thereby increasing the chances enzymes-substrates reaction. At temperatures greater than the reaction limit, the enzyme protein can experience a detrimental change in the three-dimensional arrangement of the polypeptide chain (Suhartono,1989). The effect of temperature on chitosanase activity is presented in Figure 3.

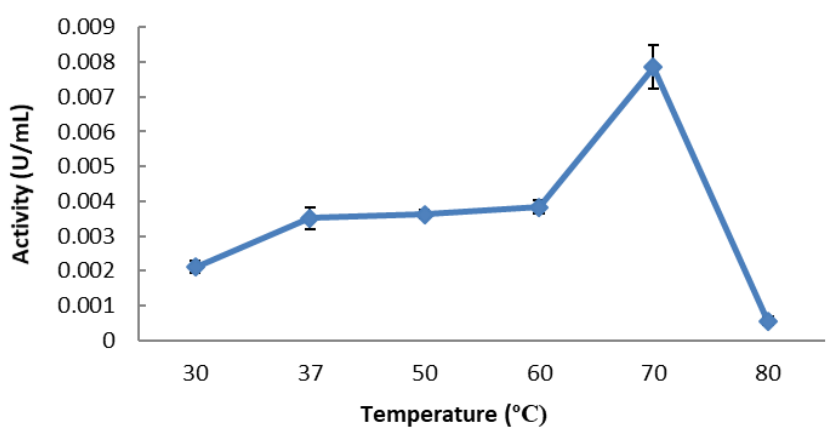

Figure 3. Effects of temperature on chitosanase activity of isolate I2.

Based on the data, the enzyme reached its highest activity at $70{ }^{\circ} \mathrm{C}$ with a value of $0.00785 \mathrm{U} / \mathrm{ml}$. Increasing temperature to $80^{\circ} \mathrm{C}$ led to decrease inactivity. This shows that enzymes can work optimally at temperatures that are different from the growth temperature of the enzymeproducing bacteria. The optimum temperature of the 12 enzyme is similar to the previous study on chitosanase enzymes from Bacillus coagulans LH2838 (Haliza, 2003). However, this result is slightly different from extracellular chitosanase produced by Bacillus subtilis $\mathrm{CH} 2$ isolated from the intestine of scorpionfish (Sebastiscus marmoratus) which has optimum $\mathrm{pH}$ and temperature of 5.5 and $60 \mathrm{oC}$, respectively (Oh et al., 2011).

Genetic identification of isolate 12 using 16s rRNA reveals that the isolate has a 95\% similarity to Bacillus cereus Strain BFE 5400. The 1438 base pairs length nucleotide sequence was used as a query.

Other Bacillus cereus strains were also known as chitosanase producers. Bacillus cereus S1 studied by Kurakake et al. (2000) produced chitosanase with 45.000 Da molecular weight and exhibited optimum activity at $\mathrm{pH} 6$ and temperature around $60^{\circ} \mathrm{C}$. Bacillus cereus D-11 isolated from Taiwan soils was characterized by $41 \mathrm{kDa}$ molecular weight with optimal $\mathrm{pH}$ and temperature were 6.0 and $60^{\circ} \mathrm{C}$, respectively (Gao et $a l ., 2008$ ).

\section{CONCLUSIONS}

The digestive tract of snakehead fish is a potential source of chitosanase-producing bacteria. Bacillus cereus Strain BFE5400 has been isolated from snakehead fish intestine and the enzyme has been partially characterized. Incubation time to produce a bacterial cell with the highest chitosanase activity was $72 \mathrm{~h}$. Enzyme activity was optimum at $\mathrm{pH} 6$ and temperature of $70^{\circ} \mathrm{C}$. Further purification is needed to remove nonenzyme protein and other components that may interfere with enzyme activity. 


\section{ACKNOWLEDGMENTS}

The authors would like to thank Sriwijaya University for funding through Sainteks Research Scheme awarded to Shanti Dwita Lestari.

\section{REFERENCES}

Ausubel, F.M., R. Brent, R.E. Kingston, D.D. Moore, J.G. Seidman, J.A. Smith \& K Struhl. 1997. Current Protocols in Molecular Biology. John Wiley \& Sons, Inc., Hoboken

Chasanah, E., Y.N. Fawzya, A. Pratitis \& T. Nurhayati. 2007. Penapisan bakteri penghasil enzim kitosanase yang berasosiasi dengan spons laut. Jurnal Pascapanen dan Bioteknologi Kelautan dan Perikanan. 2( 2): 161169

Chasanah, E., G. Patantis, D.S. Zilda, M. Ali \& Y. Risjani. 2011. Purification and characterization of Aeromonas media KLU 11.16 chitosanase isolated from shrimp waste. Journal of Coastal Development. 15 (1): 104113

Chiang, C.L., C.T. Chang \& H.Y. Sung. 2002. Purification and properties of chitosanase from a mutant of Bacillus subtilis IMR-NK1. Enzyme and Microbial Technology. (32): $260-267$

Choi Y.J., E.J. Kim, Z. Piao, Y.C. Yun \& Y.C. Shin. 2004. Purification and characterization of chitosanase from Bacillus sp. strain KCTC 0377BP and its application for the production of chitosan oligosaccharides. Applied and Environmental Microbiology. 70: 4522-4531

Ferrari, A.R., Y. Gaber \& M.W. Fraaije. 2014. A fast, sensitive and easy colorimetric assay for chitinase and cellulase activity detection. Biotechnology for Biofuels. 7: 37

Gao, X.A., W.T. Ju, W.J. Jung \& R.D. Park. 2008. Purification and characterization of chitosanase from Bacillus cereus D-11. Carbohydrate Polymers. (72): 513-520

Haliza W. 2003. Karakteristik Kitosanase Unik dari Bacillus coagulans LH 28.38 Asal Lahendong Sulawesi Utara. Tesis S2. Pascasarjana IPB, Bogor. https://repository. ipb.ac.id/handle/123456789/7993

Ibrahim, K.A., B.I. El-Eswed, K.A. Abu-Sbeih, T.A. Arafat, M.M.H. Al Omari, F.H. Darras \& A.A. Badwan. 2016. Preparation of chito-oligomers by hydrolysis of chitosan in the presence of zeolite as adsorbent. Marine Drugs. 14 (43)

Kasaai, MR., J. Arul \& G. Charlet. 2008. Fragmentation of chitosan by ultrasonic irradiation. Ultrason Sonochem. 15 (6): 1001-1008

Kasaai, M.R., J. Arul \& G. Charlet. 2013. Fragmentation of Chitosan by Acids. The Scientific World Journal
Kurakake, M., S. Yo-u, K. Nakagawa, M. Sugihara \& T. Komaki. 2000. Properties of chitosanase from Bacillus cereus S1. Current Microbiology. 40 (1): 6-9

Mathiavanan, N., V. Kabilan \& K. Murugesan. 1998. Purification, characterization and antifungal activity of chitinase from Fusarium chlamydosporum, a microparasite to groundnut rust, Puccina arachidis. Canadian Journal of Microbiology. 44:646-651

Muchtadi, D., N.S. Palupi \& M. Astawan. 1996. Enzim dalam Industri Pangan. PAU Pangan dan Gizi Institut Pertanian Bogor, Bogor, Indonesia.

Oh, C., M. De Zoysa, D-H. Kang, Y. Lee, I. Whang, C. Nikapitiya, S-J. Heo, K-T. Yoon, A. Affan \& J. Lee. 2011. Isolation, purification, and enzymatic characterization of extracellular chitosanase from marine bacterium Bacillus subtilis $\mathrm{CH} 2$. Journal Microbiology Biotechnology. 21 (10): 1021-1025

Pagnoncelli, M.G.B., N.K. de Araújo, N. M.P. da Silva N.M.P, C.F. de Assis, S. Rodrigues \& G.R. de Macedo. 2010. Chitosanase production by Paenibacillus ehimensis and its application for chitosan hydrolysis. Brazilian Archives of Biology and Technology. 53 (6): 14611468

Rydz, J., M. Musioł, B. Zawidlak-Węgrzyńska \& W. Sikorska. 2018. Present and future of biodegradable polymers for food packaging applications. Biopolymers for Food Design. 431-467

Setia, I.N \& Suharjono. 2015. Chitosanolytic assay and identification of bacteria isolated from shrimp waste based on 16S rDNA sequences. Advances in Microbiology. 5: 541-548

Shahidi, F., J.K.V. Arachchi \& Y.J. Joen. 1999. Food application of chitin and chitosan. Trends in Food Science and Technology. (10): 37-51

Somashekar, D \& R. Joseph. 1996. Chitosanases properties and applications: a review. Bioresource Technology. 55 (1): 35-45

Suhartono, M.T. 1989. Enzim dan Bioteknologi. Institut Pertanian Bogor, Bogor, Indonesia.

Sun, T., D. Zhou, J. Xie \& F. Mao. 2007. Preparation of chitosan oligomers and their antioxidant activity. European Food Research and Technology. 225 (3-4): 451-456

Swiontek-Brzezinska, M., E. Lalke-Porczyk \& W. Donderski. 2007. Chitosanolytic activity of bacteria and fung isolated from shrimp exoskeletons.Oceanological and Hydrobiological Studies. 36 (3): 101-111 